\title{
Prevalence of obesity and cardiovascular risk in patients with HIV / AIDS in Porto Alegre, Brazil
}

\author{
Prevalência de obesidade e risco cardiovascular em \\ pacientes com HIV/AIDS em Porto Alegre, Brasil
}

Andrea Francis Kroll ${ }^{12}$, Eduardo Sprinz ${ }^{3}$, Suzete Carbonell Leal ${ }^{4}$, Maria da Graça Labrêa², Sérgio Setúbal'

\begin{abstract}
Objective: The aim of this study was to discover the prevalence of overweight, obesity and cardiovascular risk in our HIV/AIDS outpatients according to sex, antiretroviral therapy and other variables. Subjects and methods: Patients underwent an anthropometric assessment. Body mass index and waist circumference were used to classify their nutritional status and their cardiovascular risk. Results: The majority of the 345 patients $(58.8 \%)$ were males. Obesity was detected in $8.3 \%$ of them; $34.2 \%$ were overweight, and $5.2 \%$ malnourished. Near half of them $(51.3 \%)$ had some cardiovascular risk, with increased risk in $24.6 \%$ of them, and substantially increased risk in $26.7 \%$ of them. Conclusions: Overweight and obesity were highly prevalent. Women were more frequently obese (OR = 3.53; IC 95\%, $1.47<\mathrm{OR}<8.69$ ), and their cardiovascular risk was often higher (OR $=6.97$; IC 95\%, $4.16<\mathrm{OR}<11.76)$. The prevalence of obesity and cardiovascular risk did not change according to antiretroviral therapy or other variables. Arq Bras Endocrinol Metab. 2012;56(2):137-41
\end{abstract}

Keywords

Overweight; obesity; body mass index; HIV; acquired immunodeficiency syndrome

\section{RESUMO}

Objetivo: Conhecer a prevalência de sobrepeso, obesidade e risco cardiovascular em nossos pacientes ambulatoriais com HIV/AIDS de acordo com o sexo, tratamento antirretroviral e outras variáveis. Sujeitos e métodos: Os pacientes foram submetidos à avaliação antropométrica. $O$ índice de massa corporal e a medida da circunferência da cintura foram utilizados para classificar o estado nutricional e o risco cardiovascular. Resultados: A maior parte dos 345 pacientes $(58,8 \%)$ era do sexo masculino. A obesidade foi detectada em $8,3 \%$ deles; $34,2 \%$ tinham sobrepeso e $5,2 \%$, desnutrição. Quase a metade $(51,3 \%)$ apresentou algum risco cardiovascular, com risco elevado em $24,6 \%$ e muito elevado em $26,7 \%$. Conclusões: 0 sobrepeso e a obesidade têm elevada prevalência. As mulheres são mais frequentemente obesas $(O R=3,53$; IC $95 \%, 1,47<$ OR $<8,69$ ) e seu risco cardiovascular é frequentemente mais alto (OR =6,97; IC $95 \%, 4,16<\mathrm{OR}<11,76)$. A prevalência de obesidade e de risco cardiovascular não se alterou conforme o tratamento antirretroviral ou outras variáveis. Arq Bras Endocrinol Metab. 2012;56(2):137-41

Descritores

Sobrepeso; obesidade; índice de massa corporal; HIV; síndrome da imunodeficiência adquirida
Programa de Pós-Graduação em Ciências Médicas, Universidade Federal Fluminense (UFF), Niterói, RJ, Brazil ${ }^{2}$ Ambulatório de Dermatologia Sanitária (ADS), Porto Alegre, RS, Brazil

${ }^{3}$ Hospital de Clínicas de Porto Alegre (HCPA), Porto Alegre, RS, Brazil

${ }^{4}$ Instituto de Administração Hospitalar e Ciências da Saúde (IACHS), Porto Alegre, RS, Brazil
Correspondence to: Andrea Francis Kroll Programa de Pós-Graduação em Ciências Médicas, Universidade Federal Fluminense,

Hospital Universitário Antônio Pedro Rua Marques do Paraná, 303 24033-900 - Niterói, RJ, Brazil andreafks@gmail.com

Received on Feb/11/2011 Accepted on Feb/23/2012

\section{INTRODUCTION}

$\mathrm{H}_{w}^{\mathrm{I}}$ V infects around 33.4 million people in the world, including 31.3 million adults between 15 and 49 years of age (1). Two million people live with the virus in Latin America (1). The first AIDS case in Brazil was described in 1980. By June 2009, there were approximately 545.000 AIDS cases, from which more than 104.000 occurred in the southern region of the 
country (2). In the same period, Rio Grande do Sul, the southernmost state, recorded more than 52.000 cases (2). The reported incidence rate in the capital of the state is the largest in the country, of 106.1 cases per 100.000 inhabitants (2).

At the beginning of epidemic, $60 \%$ to $90 \%$ of individuals with AIDS had significant malnutrition, characterized by involuntary weight loss and higher mortality $(3,4)$. However, the nutritional status of HIV/AIDS patients has changed since 1996 (3). The advent of combined antiretroviral therapy (cART) increased survival, and resulted in the emergence of complications nonexistent or not perceived, until then, and thought to be drug-related adverse effects. These complications included body fat redistribution, increased fat mass, and changes in circulating lipids and glucose metabolism, all contributing to increased cardiovascular risk (CVR) (5-12).

A study conducted in the USA with HIV-infected patients has shown that obesity is now more common than malnutrition (13). Other studies also reported high frequency of overweight and obesity, and a positive association between these problems and being female $(14,15)$. This was also observed in studies conducted in Brazil, which have shown high prevalence of overweight and obesity among HIV-positive patients (16-18).

The aim of this study was to discover the prevalence of overweight, obesity and CVR in HIV/AIDS outpatients in two reference clinics in Porto Alegre, state of Rio Grande do Sul, Brazil. It also aimed at showing whether excess weight was related to cART or other variables such as sex, length of treatment, CD4+ T lymphocyte (CD4) counts, and viral load (VL).

\section{SUBJECTS AND METHODS}

We conducted a cross-sectional study involving HIV/ AIDS outpatients of both sexes and over 18 years of age in the Ambulatório de Dermatologia Sanitária (ADS) and in the Hospital de Clínicas de Porto Alegre (HCPA), two reference services in Porto Alegre, Rio Grande do Sul, Brazil. Patients were consecutively enrolled from February to November 2006, during routine outpatient visits.

The outpatients studied were clinically stable and received no cART, or had been on cART for at least six months with two nucleoside reverse transcriptase inhibitor (NRTIs), and either a protease inhibitor (PI) or a non-nucleoside reverse transcriptase inhibitor (NNRTI). They had their CD4 count and their VL measured at least three months before the visit. We excluded patients treated with corticosteroids or anabolic steroids, and those who underwent surgery, had an opportunistic infection in the last six months, had their cART suspended for any reason, or were pregnant. This study was approved by the Ethics Committees in Research of the School of Public Health of Rio Grande do Sul and of the HCPA. All participants signed an informed consent form.

We studied the following variables: sex, age, weight, height, body mass index (BMI), waist circumference (WC), nutritional status, previous cART use, current cART scheme, time on cART, CD4 counts, and VL. Nutritional status was defined according to the BMI, calculated as the ratio between the weight in kilograms and the square of the height in meters $\left(\mathrm{kg} / \mathrm{m}^{2}\right)$. According to World Health Organization, BMI is an appropriate indicator of nutritional status in adults (19). Patients were considered obese when their BMI was equal or greater than $30 \mathrm{~kg} / \mathrm{m}^{2}$; overweight, when their BMI was between 25 and $29.9 \mathrm{~kg} / \mathrm{m}^{2}$; normal when their BMI was between 18.5 and $24.9 \mathrm{~kg} / \mathrm{m}^{2}$; and malnourished when their BMI was below $18.5 \mathrm{~kg} / \mathrm{m}^{2}$. Patients were weighed and measured without shoes and wearing light clothes by means of a physician scale with a built-in stadiometer.

As recommended by the World Health Organization (20), WC was the only parameter used to assess CVR. For men, WC $>94 \mathrm{~cm}$ indicates increased risk, and $\mathrm{WC}>102 \mathrm{~cm}$, a substantially increased risk. For women, values for increased and substantially increased risk are $>80 \mathrm{~cm}$ and $>88 \mathrm{~cm}$, respectively (20). WC was measured using an inelastic anthropometric tape with accuracy of $0.1 \mathrm{~cm}$.

Variables were initially expressed as absolute frequencies, means, and standard deviations. We used Pearson chi-square to detect differences between categorical variables, and Student's $t$ test to detect differences between means. The significance level was set at $5 \%$ $(\mathrm{p}<0.05)$. We used the Statistical Package for Social Science (SPSS) software, version 17.0, to analyze the data. Odds ratio was calculated by EpiInfo 6.4.

\section{RESULTS}

Samples of patients studied in the two health services were homogeneous and comparable (data not shown). 
Three hundred and seventy-six patients were initially enrolled. Thirty-two of them refused to participate further. From the 354 remaining subjects, 127 were from the ADS and 218 from the HCPA. Most were male $(58.8 \%)$. The predominant ethnic group was white $(78.5 \%)$, followed by blacks $(12.5 \%)$, and people with mixed ethnic inheritance $(9 \%)$. Most individuals $(60.3 \%)$ were from Porto Alegre. As for literacy, we observed that $50.4 \%$ had primary education, $30.7 \%$ had high school education, and $17.2 \%$ had college education. About two-thirds of the individuals $(74.2 \%)$ were sedentary. In relation to the cART, $40.9 \%$ of the patients used two NRTIs plus a NNRTI, 35.1\% used two NRTIs plus an IP, and $24.1 \%$ were not under treatment. Table 1 shows the cART data.

Overweight was observed in $34.2 \%$ of the patients, obesity in $8.4 \%$, and malnutrition in $5.2 \%$. Table 2 shows the nutrition status according to sex. Women were more obese than men $(\mathrm{OR}=3.53$; IC 95\%, $1.47<\mathrm{OR}$ $<8.69$ ). There was no statistically significant difference in the nutritional diagnosis according to type and length of cART, CD4 counts, or VL (Table 1). Near half (51.3\%) were at CVR; $24.6 \%$ had increased risk, and $26.7 \%$ had substantially increased risk.

Table 2 shows that $77.5 \%$ of women and $33 \%$ of men were at some degree of CVR. Women had an almost seven times higher chance of being at some degree of CVR than men $(\mathrm{OR}=6.97$; IC 95\%, $4.16<$ $\mathrm{OR}<11.76)$. Very high CVR was also more frequent in women $(51.4 \%$ vs. 9.4\%). Women had an almost five times higher chance of being at very high CVR than men $(\mathrm{OR}=4.98$; IC 95\%, $2.57<\mathrm{OR}<9.66)$.

Table 1 shows age, sex, weight, BMI, nutritional status, WC, CVR, CD4 counts, VL, and length of cART in months, according to current therapy. There were no statistically significant differences.

Table 1. Data on HIV-positive patients according to antiretroviral therapy. Porto Alegre, Rio Grande do Sul, Brazil, 2006

\begin{tabular}{|c|c|c|c|}
\hline Variables & NNRTI & PI & Untreated \\
\hline \multicolumn{4}{|l|}{ Age } \\
\hline Mean \pm SD & $43.05 \pm 9.993$ & $44.25 \pm 11.268$ & $38.66 \pm 9.669$ \\
\hline Lower range & 41.39 & 42.22 & 36.55 \\
\hline Upper range & 44.71 & 46.28 & 40.77 \\
\hline \multicolumn{4}{|l|}{ Sex } \\
\hline Male & $87(61.7 \%)$ & $67(55.4 \%)$ & $49(59 \%)$ \\
\hline \multicolumn{4}{|l|}{ Weight (kg) } \\
\hline Mean \pm SD & $69.14 \pm 12.466$ & $68.64 \pm 14.036$ & $68.96 \pm 13.404$ \\
\hline \multicolumn{4}{|l|}{ BMI $\left(\mathrm{kg} / \mathrm{m}^{2}\right)$} \\
\hline Mean \pm SD & $24.684 \pm 3.62177$ & $25.226 \pm 5.15662$ & $24.949 \pm 4.37328$ \\
\hline \multicolumn{4}{|l|}{ Nutritional status } \\
\hline Malnourished & $6(4.3 \%)$ & $8(6.6 \%)$ & $4(4.8 \%)$ \\
\hline Normal & $75(53.2 \%)$ & $63(52.1 \%)$ & $42(50.6 \%)$ \\
\hline Overweight & $52(36.9 \%)$ & 35 (28.9\%) & $31(37.3 \%)$ \\
\hline Obese & $8(5.7 \%)$ & $15(12.4 \%)$ & $6(7.2 \%)$ \\
\hline \multicolumn{4}{|l|}{ WC (cm) } \\
\hline Mean \pm SD & $89.11 \pm 10.087$ & $90.50 \pm 11.915$ & $87.87 \pm 11.080$ \\
\hline \multicolumn{4}{|l|}{ Cardiovascular risk } \\
\hline No risk & $72(51.1 \%)$ & $54(44.6 \%)$ & $42(50.6 \%)$ \\
\hline Increased risk & $34(24.1 \%)$ & $28(23.1 \%)$ & $23(27.7 \%)$ \\
\hline Substantially increased risk & $35(24.8 \%)$ & $39(32.2 \%)$ & $18(21.7 \%)$ \\
\hline \multicolumn{4}{|l|}{ CD4 } \\
\hline Mean \pm SD & $536.84 \pm 247.817$ & $498.50 \pm 250.62$ & $504.80 \pm 237.89$ \\
\hline \multicolumn{4}{|l|}{ VL (log) } \\
\hline Mean \pm SD & $1.8961 \pm 0.63299$ & $2.0580 \pm 0.81672$ & $3.9394 \pm 0.88774$ \\
\hline \multicolumn{4}{|l|}{ Length of cART (months) } \\
\hline Mean \pm SD & $58.11 \pm 32.696$ & $73.89 \pm 37.775$ & - \\
\hline Total $(n=345)$ & 141 & 121 & 83 \\
\hline
\end{tabular}

Note: all values were not significant. 
Table 2. Nutritional status and cardiovascular risk according to sex. Porto Alegre, Rio Grande do Sul, Brazil, 2006

\begin{tabular}{llll}
\hline Variables & \multicolumn{1}{c}{ Male } & \multicolumn{1}{c}{ Female } & \multicolumn{1}{c}{ Total } \\
\hline Nutritional status & & & \\
Malnourished & $12(5.9 \%)$ & $6(4.2 \%)$ & $18(5.2 \%)$ \\
$\quad$ Normal & $112(55.2 \%)$ & $68(47.9 \%)$ & $180(52.2 \%)$ \\
Overweight & $70(34.5 \%)$ & $48(33.8 \%)$ & $118(34.2 \%)$ \\
$\quad$ Obese & $9(4.4 \%)$ & $20(14.1 \%)$ & $29(8.4 \%)$ \\
Cardiovascular risk** & & & \\
$\quad$ No risk & $136(67 \%)$ & $32(22.5 \%)$ & $168(48.7 \%)$ \\
$\quad$ Increased risk & $48(23.6 \%)$ & $37(26.1 \%)$ & $85(24.6 \%)$ \\
$\quad$ Substantially increased risk & $19(9.4 \%)$ & $73(51.4 \%)$ & $92(26.7 \%)$ \\
Total & 203 & 142 & 345 \\
\hline
\end{tabular}

* Pearson Chi-Square $=10.575 ; p=0.014$.

** Pearson Chi-Square $=89.513 ; p<0.001$.

\section{DISCUSSION}

We found that the prevalence of excess weight (overweight or obesity) was high and greater than the prevalence of malnutrition among HIV/AIDS patients, findings that agree with other studies $(13,16,17,21)$. We found similar frequencies of overweight in women and men. However, like other studies (13-16), obesity was more frequent in women $(14 \% v s .4 \%)$. Amorosa and cols. (13), studying obesity prevalence among American HIV-positive patients, found an even greater difference $(28 \%$ vs. $11 \%)$. Similar to Jaime and cols. (16), we found no statistically significant differences in nutritional status according to therapy, CD4 counts, or VL.

Data from a Familiar Income Survey conducted in 2008-2009 by the Brazilian Ministry of Health show that excess weight involves $50.1 \%$ of men and $48 \%$ of women, and that obesity is present in $12.5 \%$ of men and $16.9 \%$ of women (22). Southern Brazil has the highest percentage of overweight individuals, $56.8 \%$ in men and $51.6 \%$ in women. In this part of the country, $15.9 \%$ of men and $19.6 \%$ of women are obese. Thus, the rate of obesity in our HIV-positive female patients $(14.1 \%)$ is very close to that of the Brazilian population in general (16.9\%). This finding was different for males (4.4\% in our study vs. $12.5 \%$ in the overall population).

HIV patients had increased WC when compared to non-HIV controls (23). Near half of our outpatients $(51.3 \%)$ had CVR, according to their WC. We also observed a significant positive association between CRV and being female. Jaime and cols. (16), using WC measurements in HIV-positive patients, found a substantially increased risk in $6.4 \%$ men and in $32.7 \%$ wo- men, frequencies lower than those found in our study, $9.4 \%$ in men and $51.4 \%$ in women. Greater WC is significantly and independently associated with subclinical atherosclerosis (24). It was not possible to compare our CVR values with those of other studies of HIV patients, as different parameters were used, such as the study by Farhi and cols. (18), who studied the waist-to-hip ratio (and found it increased in $28.9 \%$ of their patients), or the study by Oketch and cols. (25), who also found an increase in this ratio. However, Pao and cols. (26) observed that increases in WC occur less frequently in people with HIV infection. Another limitation in comparing our data with those of other researchers was that CVR in other studies was often estimated according to the Framingham score $(27,28)$.

Our data and other studies confirm that overweight and obesity are a growing health problem in HIV-positive population. This may be explained by greater survival and less opportunistic infections following the introduction of cART. For this population, changes in lifestyle and, when needed, antilipemic drug therapy are necessary to reduce the prevalence of overweight, obesity, and metabolic complications, such as dyslipidemia and insulin resistance, which contribute to morbidity.

In our AIDS/HIV-positive patients, excess weight (overweight and obesity) was the most common nutritional disorder, especially among women, as occurs in the Brazilian population in general. In our study, WC-related CVR was also increased in women.

As for antiretroviral therapy, we found no statistically significant association between overweight, obesity, estimated CVR, and treatment with PI, NNRTI or no therapy. In our study, treatment apparently had no effect on the prevalence of overweight and obesity.

Acknowledgments: We are grateful to the patients who took part in this investigation. This study was made possible by the support from the Nutrition Service of the Ambulatório de Dermatologia Sanitária de Porto Alegre (ADS), Ambulatório de Infectologia to the Hospital de Clínicas de Porto Alegre (HCPA), and the Department of Epidemiology and Biostatistics (GPPG/HCPA). SA Oliveira contributed to the critical review of the paper. LGC Velarde participated in data interpretation.

Disclosure: no potential conflict of interest relevant to this article was reported.

\section{REFERENCES}

1. UNAIDS/World Health Organization. AIDS Epidemic Update: December 2009. Available from: http://data.unAIDS.org/pub/Report/2009/2009_epidemic_update_en.pdf. Access on: Dec 8, 2009. 
2. Ministério da Saúde. Boletim Epidemiológico - AIDS e DST. Ano $\mathrm{VI}-\mathrm{n}^{0} 1-27^{\mathrm{a}}$ a $2^{\mathrm{a}}$ - semanas epidemiológicas - julho a dezembro de 2008. Ano VI $-n^{\circ} 1-01^{\mathrm{a}}$ a $26^{\mathrm{a}}$ - semanas epidemiológicas - janeiro a junho de 2009. Available from: http://www2.AIDS.gov.br/ sites/default/files/Boletim2010.pdf. Access on: Ago 13, 2010.

3. Coppini LZ, Ferrini MT. Síndrome da imunodeficiência adquirida. In: Cuppari L, editor. Nutrição Clínica no Adulto. São Paulo: Manole; 2005.

4. Sprinz E, Finkelszteijn A. Rotinas de HIV e AIDS. In: Nascimento C, editor. Cuidados nutricionais: avaliação e manejo. Porto Alegre: Artes Médicas; 1999.

5. Araújo PSR, Ximenes RAA, Lopes CFC, Duarte JY, Silva, MM, Carneiro EM. Antiretroviral treatment for HIV infection/AIDS and the risk of developing hyperglycemia and hyperlipidemia. Rev Inst Med Trop. 2007;49(2):73-8.

6. Levy AR, Mccandless L, Harrigan RP, Hogg RS, Bondy G, Iloeje $U H$, et al. Changes in lipids over twelve months after initiating protease inhibitor therapy among persons treated for HIV/AIDS. Lipids Health Dis. 2005;4:1476-511.

7. Valente AMM, Reis AF, Machado DM, Succi RCM, Chacra AR. Alterações metabólicas da síndrome lipodistrófica do HIV. Arq Bras Endocrinol Metab. 2005;49(6):871-81.

8. Rodríguez RP. Manual de Nutrición y Sida. $3^{\mathrm{a}}$ Edición. Madri: Ed. Rosa Pólo; 2002.

9. Galli M, Ridolfo AL, Adorni F, Gervasoni C, Ravasio L, Corsico L, et al. Body habitus changes and metabolic alterations in protease inhibitor-naive HIV-1-infected patients treated with two nucleoside reverse transcriptase inhibitors. J Acquir Immune Defic Syndr. 2002;29(1):21-31.

10. Hadigan C, Meigs JB, Corcoran C, Rietschel P, Piecuch S, Basgoz $\mathrm{N}$, et al. Metabolic abnormalities and cardiovascular disease risk factors in adults with human immunodeficiency virus infection and lipodystrophy. Clin Infect Dis. 2001;32(1):130-9.

11. Silva M, Skolnik PR, Gorbach SL, Spiegelman D, Wilson IB, Fernández-Difranco $M G$, et al. The effect of protease inhibitors on weight and body composition in HIV-infected patients. Acquir Immune Defic Syndr. 1998;12(13):1645-51.

12. Miller KD, Jones E, Yanvoski JA, Shankar R, Feuerstein I, Falloon J. Visceral abdominal-fat accumulation associated with use of indinavir. Lancet. 1998;351(9106):871-5.

13. Amorosa V, Synnestvedt M, Gross R, Friedman H, Macgregor RR, Gudonis $D$, et al. A table of 2 epidemics: the intersection between obesity and HIV infection in Philadelphia. J Acquir Immune Defic Syndr. 2005;39(5):557-61.

14. Kruzich LA, Marquis GS, Wilson CM, Stephensen CB. HIV-infected US youth are at high risk of obesity and poor diet quality: a challenge for improving short-and long-term health outcomes. J Am Diet Assoc. 2004;104(10):1554-60.

15. Shuter J, Chang CJ, Klein RS. Prevalence and predictive value of overweight in an urban HIV care clinic. Acquir Immune Defic Syndr. 2001;26(3):291-7.
16. Jaime PC, Florindo AA, Latorre MRDO, Brasil BG, Santos ECMD, Segurado AAC. Prevalência de sobrepeso e obesidade abdominal em indivíduos portadores de HIV/AIDS, em uso de terapia anti-retroviral de alta potência. Rev Bras Epidemiol. 2004;7(1):65-72.

17. Leite LHM, Sampaio ABMM. Metabolics abnormalities and overweight in HIV/AIDS persons-treated with antiretroviral therapy. Rev Nutr. 2008;21(3):277-83.

18. Farhi L, Lima DB, Cunha CB. Dyslipidemia in HIV/AIDS patients in antiretroviral therapy in a university hospital, Rio de Janeiro, Brazil. J Bras Patol Med Lab. 2008;44(3):175-84.

19. Fagundes AA. Vigilância alimentar e nutricional - Sisvan: orientações básicas para a coleta, processamento, análise de dados e informação em serviços de saúde. Brasília: Ministério da Saúde; 2004.

20. World Health Organization. Waist circumference and waist-hip ratio: report of a WHO expert consultation. Geneva, Switzerland: WHO, 2008.

21. Hendricks KM, Erzen HD, Wanke CA, Tang AM. Nutrition issues in the HIV-infected injection drug user: findings from the nutrition for healthy living cohort. J Am Coll Nutr. 2010;29(2):136-43.

22. Ministério da Saúde. Pesquisa de Orçamentos Familiares 20082009: antropometria e estado nutricional de crianças, adolescentes e adultos no Brasil. Rio de Janeiro: IBGE; 2010.

23. Lo J, You SM, Wei J, Canavan B, Grinspoon S. Relationship of peak growth hormone to cardiovascular parameters, waist circumference, lipids and glucose in HIV-infected patients and healthy adults. Clin Endocrinol (Oxf). 2009;71(6):815-22.

24. De Socio GV, Martinelli C, Ricci E, Orofino G, Valsecchi L, Vitiello P, et al. Relations between cardiovascular risk estimates and subclinical atherosclerosis in naive HIV patients: results from the HERMES study. Int J STD Aids. 2010;21(4):267-72.

25. Oketch JA, Paterson M, Maunder EW, Rollins NC. Too little, too late: comparison of nutritional status and quality of life of nutrition care and support recipient and non-recipients among HIV-positive adults in KwaZulu-Natal, South Africa. Health Policy. 2011;99(3):267-76.

26. Pao V, Lee GA, Grunfeld C. HIV therapy, metabolic syndrome, and cardiovascular risk. Curr Atheroscler Rep. 2008;10(1):61-70.

27. Ena J, Benito C, Llácer P, Pasquau F, Amador C. Abnormal body fat distribution and type of antiretroviral therapy as predictors of cardiovascular disease risk in HIV-infected patients. Med Clin (Barc). 2004;122(19):721-6.

28. Barros ZM, Ximenes RAA, Miranda-Filho DMB, Albuquerque MFPM, Melo HRL, Carvalho EH, et al. Comparison between the Framingham and prospective cardiovascular of Münster scores for risk assessment of coronary heart disease in human immunodeficiency virus-positive patients in Pernambuco, Brazil. Metab Syndr Relat Disord. 2010;8(6):489-97. 